\title{
MODE OF ACTION OF ADRIAMYCIN ON HELA S-3 CELLS IN VITRO
}

\author{
Kozo Kitaura, Ryoji Imai, Yukiko Ishmara, \\ Hideyuki Yanai and Hirosht Takahira
}

Fuji Research Laboratory, Kyowa Hakko Kogyo Co., Ltd. 1188, Shimotogari, Nagaizumi-machi, Sunto-gun, Shizuoka-ken, Japan

(Received for publication June 16, 1972)

The effect of adriamycin on HeLa S-3 cells grown in monolayers was studied. The growth of HeLa S-3 cells was clearly inhibited at low doses of 0.05 and $0.10 \mathrm{mcg} / \mathrm{ml}$. One of the earliest changes of the cells treated with adriamycin was the rapid depression in mitotic frequency. Adriamycin caused inhibition of cell division even when added at the end of DNA synthesis phase. Adriamycin inhibited RNA synthesis more severely than DNA and protein syntheses. Moreover, the specific inhibition of RNA synthesis was observed in logarithmically growing cultures under conditions which permitted normal syntheses of DNA and protein. However, the degree of inhibition of RNA synthesis was reduced in synchronized cultures with excess thymidine. The mode of action of adriamycin is discussed.

Adriamycin is a new antitumor antibiotic of the anthracycline group isolated from cultures of Streptomyces peucetius var. caesius ${ }^{1)}$. Its chemical structure is very close to that of daunomycin from which it differs only in having a hydroxyl group substituted for a hydrogen atom of the acetyl radical.

The effect of adriamycin on several experimental tumor systems has recently been reported from our laboratory ${ }^{2)}$. The present studies were undertaken to show the cytological effects of adriamycin on HeLa S-3 cells in vitro. Furthermore, studies were made of its action on the biosynthesis of macromolecules by HeLa S-3 cells.

\section{Materials and Methods}

Chemicals: Adriamycin was obtained from Farmitalia Research Laboratory, Italy. Thymidine-6- ${ }^{3} \mathrm{H}$ with specific activity of $5.0 \mathrm{Ci} / \mathrm{mmole}$, uridine-5- ${ }^{3} \mathrm{H}$ with specific activity of $15 \mathrm{Ci} / \mathrm{mmole}$ and leucine $-4,5-{ }^{3} \mathrm{H}$ with specific activity of $32 \mathrm{Ci} / \mathrm{mmole}$ were purchased from Daiichi Pure Chemicals Co., Ltd.

Tissue culture procedures: Clone S-3 of HeLa cells was used in these experiments. This clone was cultured in Roux bottles containing $50 \mathrm{ml}$ of growth medium which consisted of YLE basal medium (EARLE's balanced salt solution containing $0.1 \%$ yeastolate, $0.5 \%$ lactalbumin hydrolysate and $0.11 \%$ sodium bicarbonate) supplemented with $10 \%$ calf serum. For observation of the effect of adriamycin on the growth of cells, a fully grown culture was treated with $0.1 \%$ trypsin solution, and the released cells were suspended in the above medium to approximately $2 \times 10^{5}$ cells per $\mathrm{ml}$. One $\mathrm{ml}$ of the suspension was inoculated into each culture tube and incubated at $37^{\circ} \mathrm{C}$ for 24 hours in a slanted position. All experiments on asynchronous populations were performed on cells in the logarithmic phase of growth. Adriamycin at desired concentration was added on 0 day. Three tubes 
per group were prepared for all experiments.

Synchronized cell culture: The two-day-old tube cultures in the growth medium were replaced by the medium containing $2 \mathrm{~mm}$ thymidine ${ }^{3,4)}$. After 24 hours, the state of thymidine excess was ended by washing the cells three times with the prewarmed normal medium, and incubation was initiated again in desired test media at $37^{\circ} \mathrm{C}$. The start of the incubation was referred to as "zero hour". The replacement of medium and the washing procedures were performed at $37^{\circ} \mathrm{C}$ as much as possible to avoid any cold shock during the synchronization of cultures. Under these conditions, DNA synthesis continued to 6 th hour, and the cell number nearly doubled by 13 th hour or so.

Incorporation of labelled precursors into nucleic acid and protein: The rates of DNA, RNA and protein syntheses were determined by measuring the incorporation of thymidine${ }^{3} \mathrm{H}(0.2 \mu \mathrm{Ci} / \mathrm{ml})$, uridine ${ }^{-3} \mathrm{H}(0.4 \mu \mathrm{Ci} / \mathrm{ml})$ and leucine ${ }^{3} \mathrm{H}(1.3 \mu \mathrm{Ci} / \mathrm{ml})$, respectively, into acidinsoluble material during a 60 -minute pulse. Immediately after the incubation at $37^{\circ} \mathrm{C}$, the reaction was terminated by rapid chilling in an ice bath. The medium containing radioactive precursors was removed by decantation, and the monolayers adhering to the glass surface were gently washed three times with cold PBS (DulBEcco's phosphate-buffered saline) followed by successive washes with $4 \%, 2 \%$ and $1 \%$ cold PCA (perchloric acid) respectively two times for 5 minutes per time. The cell sheets were then rinsed with water and permitted to dry. The dried cell residues were dissolved in $2.0 \mathrm{ml}$ of $1 \mathrm{~N} \mathrm{NH}_{4} \mathrm{OH}$, and aliquots were taken for analysis. Isotopic determination was carried out by drying aliquots planted on clean aluminum planchets and then counting the radioactivity in a low background windowless gas flow counter (Aloka JDC-104 B).

Cytological observation: For cytological studies, monolayers were prepared by planting $2 \mathrm{ml}$ of YLE medium containing $1 \times 10^{5}$ cells per $\mathrm{ml}$ on cover slips in small tubes. After a period noted, cover slips were taken out of the culture tubes, washed gently with Hanks' solution, and fixed with $70 \%$ methanol for one minute and with absolute alcohol 30 seconds. Thereafter, GiEmsa staining was performed, and the number of mitotic figures per 1,000 cells was counted.

Determination of cell number: The monolayers were incubated in $0.1 \mathrm{M}$ citric acid$0.05 \%$ crystal violet solution at $37^{\circ} \mathrm{C}$ for one hour, and the subsequent bare nuclei were counted under a microscope using a hemocytometer.

\section{Results}

Effect of Adriamycin on Logarithmically Growing HeLa S-3 Cells

HeLa S-3 cells kept under the conditions described above grew exponentially for at least three generations, and the generation time calculated by means of counting the total cell nuclei by a hemocytometer was $26 \sim 28$ hours.

As shown in Fig. 1, adriamycin can inhibit the growth of HeLa S-3 cells at doses. from 0.05 to $5.00 \mathrm{mcg} / \mathrm{ml}$.

At the dose of $0.025 \mathrm{mcg} / \mathrm{ml}$, the cells continued to grow until 4 th day following the exposure. With 0.05 and $0.10 \mathrm{mcg} / \mathrm{ml}$ of adriamycin, cultures started to grow on the first day of incubation, but significant inhibition could be seen from the second day and cytostatic action was observed. Significant inhibition of the growth, or cytocidal action, was observed from the first day after treatment with 1.00 and $5.00 \mathrm{mcg} / \mathrm{ml}$.

\section{Effect of Adriamycin on Mitotic Index}

For the purpose of investigating more precisely the effect of adriamycin on HeLa S-3 cells, experiments were carried out to determine the rate of flow of the cells into the mitotic stage at various times after treatment. 
Fig. 1. Inhibition of division of logarithmically growing HeLa S-3 cells by adriamycin.

Adriamycin in the indicated amounts $(\mathrm{mcg} / \mathrm{ml}$ ) was added 24 hours after cell seeding, and the number of cell nuclei was determined and averaged in duplicate cultures $1,2,3$ and 4 days later.

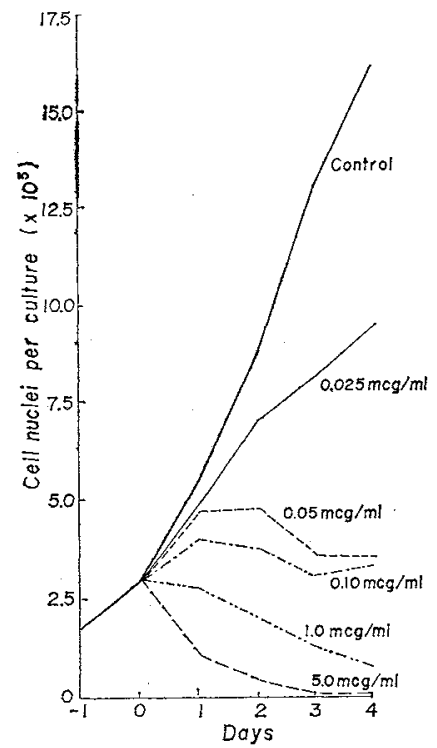

Fig. 2. Mitotic frequencies of HeLa S-3 cells treated with adriamycin.

Cells were grown on coverslips as described in the text, and 24 hours after cell seeding, adriamycin at the desired concentations $(\mathrm{mcg} / \mathrm{ml})$ was added. The metaphase figures were counted at the times indicated.

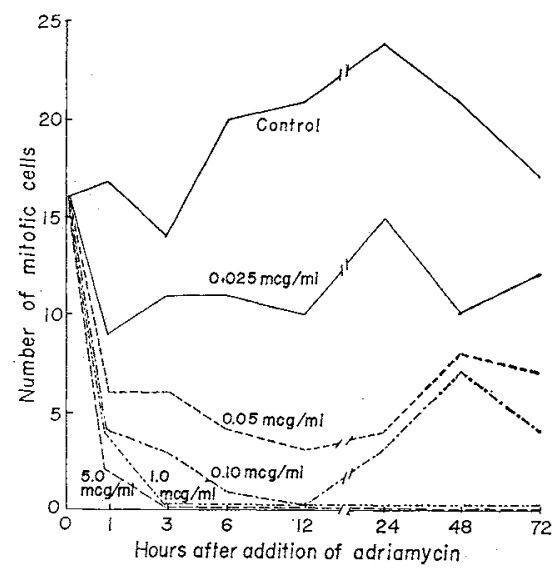

As shown in Fig. 2, the frequency of mitosis rapidly decreased depending upon the dose within one hour after treatment at various concentrations.

At a low dose of $0.025 \mathrm{mcg} / \mathrm{ml}$, the frequency of mitosis was partially inhibited in the first one hour but thereafter rose. At 0.05 and $0.10 \mathrm{mcg} / \mathrm{ml}$, the frequency decreased gradually in 12 hours, but thereafter a large number of cells with multipolar mitosis, chromosome shrinkage and scattering of chromosomes were produced. The mitotic frequency practically disappeared within 3 hours following the exposure to high doses of adriamycin such as 1.00 and $5.00 \mathrm{mcg} / \mathrm{ml}$.

On the basis of the above observations, it can be concluded that the stage prior to initiation of mitosis is particularly sensitive to the action of adriamycin.

Effect of Adriamycin on Biosynthesis of Macromolecules in Logarithmically Growing HeLa S-3 Cells

Adriamycin inhibited the incorporation of suitable precursors into RNA more than into DNA or protein as shown in in Fig. 3. At high doses of 1.00 and $5.00 \mathrm{mcg} /$ $\mathrm{ml}$, adriamycin inhibited rapidly both DNA and RNA syntheses within 2 hours, but 0.05 and $0.10 \mathrm{mcg} / \mathrm{ml}$, doses highly effective in blocking cell division, as shown in Fig. 2, had little effect on DNA synthesis in this experimental system. However, at 0.05 and $0.10 \mathrm{mcg} / \mathrm{ml}$, RNA synthesis, decreasing gradually in 12 hours, was inhibited by $44 \%$ and $58 \%$ respectively at 12 th hour.

On the other hand, protein synthesis was scarcely inhibited at $0.05,0.10$ and 1.00 $\mathrm{mcg} / \mathrm{ml}$. The inhibition of protein synthesis at the high dose of $5.00 \mathrm{mcg} / \mathrm{ml}$ is considered to be a secondary action caused by earlier significant inhibition of DNA and RNA syntheses. 
Effect of Adriamycin on Biosynthesis of Macromolecules in Synchronized HeLa S-3 Cells

The study of synchronizd cultures has revealed that the replication of a mammalian cell is a cyclic process involving the sequential activation or expression of specific genetic information ${ }^{5)}$. To obtain detailed information about the metabolic events which occur during the cell division cycle, experiments Fig. 3. Effect of adriamycin on syntheses of DNA, RNA and protein in of logarithmically growing HeLa S-3 cells. After 24 hours of growth, fresh medium with adriamycin was added to cultures. The labelled precursors were added 30 minutes before the respective times indicated, and the radioactivity was measured after one-hour incorporation. Al1 the values represent the averages of duplicate cultures.

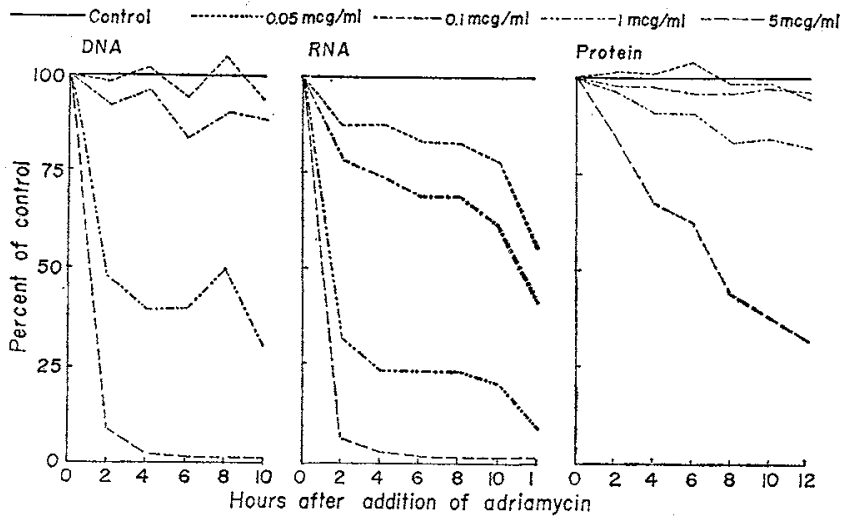
were carried out with adriamycin and synchronized HeLa S-3 cells.

Fig. 4 shows the effect of increasing concentration of adriamycin on DNA, RNA and protein syntheses in synchronized cultures. At 0.05 and $0.10 \mathrm{mcg} / \mathrm{ml}$, neither DNA synthesis nor protein synthesis was affected. However, RNA synthesis had decreased by 6 hours, and the maximum inhibition was $22 \%$ at $0.10 \mathrm{mcg} / \mathrm{ml}$. At a high concentration of adriamycin, $1.00 \mathrm{mcg} / \mathrm{ml}$, DNA and RNA syntheses were inhibited signifcantly without any effect on protein synthesis. The maximum inhibition of DNA synthesis was $58 \%$ at the 4 th hour after treatment and that of RNA synthesis was $77 \%$ at the 6 th hour.

Fig. 4. Effect of adriamycin on syntheses on DNA, RNA and protein in synchronized HeLa S-3 cells. Adriamycin at various concentrations was added at 0 hour after excess thymidine was removed. The labelled precursors were added 30 minutes before the respective times indicated, and the radioactivity was measured after one-hour incorporation. Each figure represents the average of duplicate cultures.

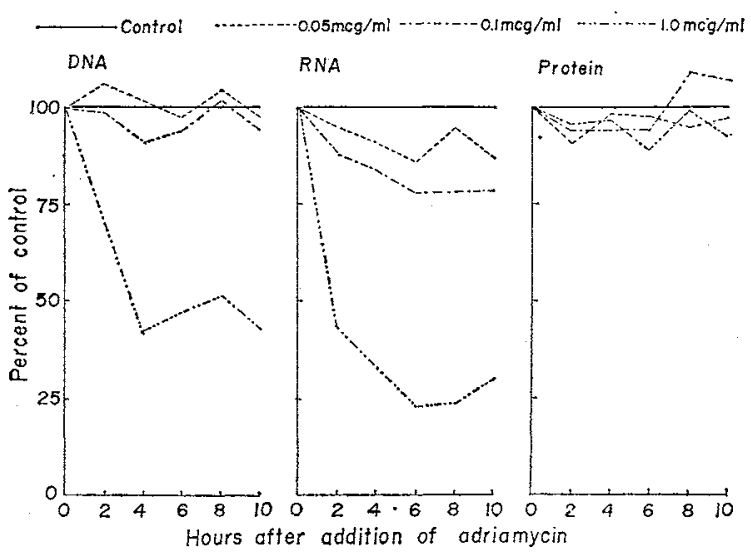

Fig. 5. Effect of delaying the addition of adriamycin on the cell division in synchronized culture of HeLa S-3 cells.

Adriamycin $(0.10 \mathrm{mcg} / \mathrm{ml})$ was added 0,2 , 4 and 6 hours after the synchronized culture was initiated. The number of cell nuclei was counted at the times indicated. All values represent the averages of duplicate cultures.

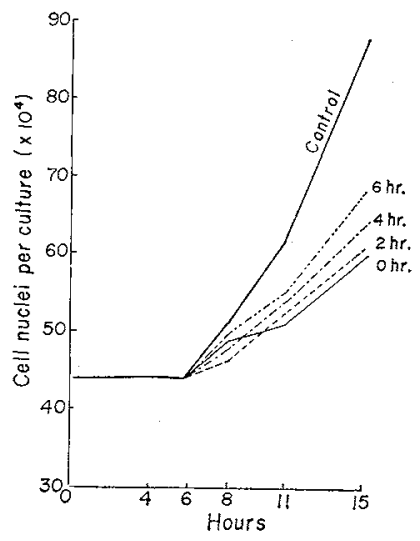


Thus, the inhibition of RNA synthesis in synchronized cultures caused by adriamycin occurred earlier and was somewhat greater than that of DNA synthesis. However, the inhibition of RNA synthesis in synchronized cultures at 0.05 and 0.10 $\mathrm{mcg} / \mathrm{ml}$ was much less than that in logarithmically growing cultures.

Effect of Delaying the Addition of Adriamycin on Cell Division in Synchronized Cultures of HeLa S-3 Cells

In order to dissociate more clearly the effect of adriamycin on DNA synthesis from its effect on cell division, synchronized cultures were treated with adriamycin, $0.10 \mathrm{mcg} / \mathrm{ml}$, at various stages of the DNA synthesis phase. The results are shown in Fig. 5.

If adriamycin was added at 0 hour, the rate of cell division was inhibited about $65 \%$ at 15 hours after treatment. The percent of inhibition was slightly less, if adriamycin was added at the 2 nd hour of incubation or later. Addition of adriamycin at the 6 th hour, when DNA synthesis had virtually finished and just before mitosis began, still caused inhibition of cell divison.

Considering that this concentration of adriamycin, $0.10 \mathrm{mcg} / \mathrm{ml}$, affected DNA synthesis only slightly, these results suggest that the effect of adriamycin on DNA synthesis is not responsible for inhibition of cell division.

\section{Discussion}

In this report, the authors have presented the studies made to elucidate the mechanism of action of adriamycin on HeLa S-3 cells in vitro.

Adriamycin inhibited significantly the growth of $\mathrm{HeLa} \mathrm{S}-3$ cells at $0.05 \sim 5.00 \mathrm{mcg} / \mathrm{ml}$. Following the addition of 0.05 to $5.00 \mathrm{mcg} / \mathrm{ml}$, a rapid depression of mitotic index occurred within one hour. Thus, it can be concluded that the stage prior to initiation of mitosis is particularly sensitive to the action of adriamycin and that the first effect of adriamycin is to prevent the cells from entering the visible stage of mitosis. This was confirmed by the experiment with synchronized cultures; that is, the addition of adriamycin just before the beginning of mitosis still caused inhibition of cell division.

On the other hand, in logarithmically growing cultures, adriamycin inhibited RNA synthesis more markedly than DNA synthesis, but it had no effect on protein synthesis. At 0.05 and $0.10 \mathrm{mcg} / \mathrm{ml}$, doses effective in blocking cell division, adriamycin inhibited RNA synthesis selectively without any effect on DNA and protein syntheses.

However, the inhibition of RNA synthesis at 0.05 and $0.10 \mathrm{mcg} / \mathrm{ml}$ was diminished in synchronized cultures with excess thymidine. Synthesis of DNA and protein was not affected at these doses. Treatment of cells with excess thymidine caused the blocking of DNA synthesis, but after removal of thymidine, the cell cycle went on to $G_{2}$ phase and the mitotic phase. Thus, $G_{1}$ phase was lacking in our synchronized system. One may, therefore, suggest that adriamycin at 0.05 and $0.10 \mathrm{mcg} / \mathrm{ml}$ affected the $G_{1}$ phase of the cell cycle in logarithmically growing HeLa S-3 cells, and consequently that the synthesis of RNA was inhibited much more than in synchronized cultures. At higher concentrations of 1.00 and $5.00 \mathrm{mcg} / \mathrm{ml}$, adriamycin probably affects cells in all stages of the cycle.

$\mathrm{W}_{\mathrm{ANG}}$ et al. ${ }^{6)}$ reported that DNA and RNA syntheses in $\mathrm{L}-1210$ cells in vitro were inhibited by $59 \%$ and $32 \%$ respectively following the exposure to $1 \times 10^{-5} \mathrm{M}$ of adriamycin for 2.5 hours. Most recently, $\mathrm{K}_{\mathrm{IM}}$ et al. ${ }^{7)}$ showed that the rates of DNA and RNA syntheses in HeLa cells were promptly reduced to about $20 \%$ and $50 \%$ of the control, respectively, within one hour after exposure to $1.00 \mathrm{mcg} / \mathrm{ml}$ of adriamycin.

These results are inconsistent with our observation. This discrepancy could be due 
to the difference in the reaction time of the drug or the cell strain employed. However, it was shown by Silvestrini et al. ${ }^{3)}$ that syntheses of DNA and RNA in HeLa cells evaluated autoradiographically were markedly inhibited by adriamycin and that inhibition of RNA synthesis after incubation for 2 hours at low concentrations of 0.1 to $0.5 \mathrm{mcg} / \mathrm{ml}$ was more significant than that of DNA synthesis. They suggested that there was blockage of synthesis of nuclear, particularly nucleolar RNA.

On the other hand, though some of the antimetabolic effects of daunomycin, which is very similar to adriamycin in structure, have been described repeatedly ${ }^{9,10,11}$, the correlation between the antimetabolic effects and the antimitotic activity is not clear. Recently, Silvestrini et al. ${ }^{12)}$ showed that daunomycin at low concentrations affected mainly the $G_{1}$ and $G_{2}$ phases in the cell cycle of synchronized cultures of rat fibroblasts. These results are in favor of our observation. As suggested by PIGRAM et al. ${ }^{13)}$, the direct interaction of daunomycin with DNA will be also possible.

Further studies on the correlation between the antimetabolic effect of adriamycin and the antimitotic activity in synchronized HeLa S-3 cells are currently in progress.

\section{References}

1) Arcamone, F.; G. Franceschi, S. Tenco \& A. Selva: Adriamycin (14-hydroxydaunorubicin), a novel antitumor antibiotic. Tetrahedron Letters 1969-13:1007 1010, 1969

2) Kitaura, K.; Y. Wathanabe, Y. Ishihara \& H. Takahrra: Studies on antitumor activity of adriamycin. Jap. J. Antibiotics $25: 65 \sim 71,1972$

3) Bootsma, D.; L. BUdKe \& O. VOS: Studies on synchronous division of tissue culture cells initiated by excess thymidine. Exptl. Cell Res. $33: 301 \sim 309,1964$

4) Krм, J.H.; S. H. Krm \& M. L. Eidrnoff : Cell viability and nucleic acid metabolism after exposure of HeLa cells to excess thymidine and deoxyadenosine. Biochem. Pharm. 14:1821 1829,1965

5) Mueller, G. C.; K. Kajiwara, E. Stubblefield \& R. R. Rueckert : Molecular events in the reproduction of animal cells. I. The effect of puromycin on the duplication of DNA. Cancer Res. 22 : 1084 1090, 1962

6) Wang, J.; D. S. Chervinsky \& J. Rosen : A comparative biochemical study of adriamycin and daunomycin. Proc. Am. Assoc. Cancer Res. $12: 77,1971$

7) Krм, S. H. \& J. H. Kim : Lethal effect of adriamycin on the division cycle of HeLa cells. Cancer Res. $32: 323 \sim 325,1972$

8) Silvestrini, R.; C. Gambarucci \& T. Dasdia: Attività biologica dell'adriamicina in vitro. Tumori $56: 137 \sim 148,1970$

9) Di Marco, A.; R. Siluvestrint, S. Di Marco \& T. Dasdia: Inhibiting effect of the new cytotoxic antibiotic, daunomycin on nucleic acid and mitotic activity of HeLa cells. J. Cell Biol. 27 : 545 550, 1965

10) Rusconi, A.: Different binding sites in DNA for actinomycin and daunomycin. Biochim. Biophys. Acta $123: 627 \sim 630,1966$

11) Silvestrini, R.; A. Di Marco, S. Di Marco \& T. Dasdia: Azione della daunomicina sul metabolismo degli acidic nuclei di cellule normali e neoplastiche coltivate in vitro. Tumori 49 : $399 \sim 412,1963$

12) Silvestrini, R.; A. Di Marco \& T. Daspia: Interference of daunomycin with metabolic events of the cell cycle in synchronized cultures of rat fibroblasts. Cancer Res. 30:966 973, 1970

13) Pigram, W. J.; W. Fuller \& L. D. Hamilton: Stereochemistry of intercalation: Interaction of daunomycin with DNA. Nature New Biol. $235: 17 \sim 19,1972$ 